\title{
TURKISH VALIDITY AND RELIABILITY OF WATSON-GLASER CRITICAL THINKING APPRAISAL TEST'S SHORT FORM*
}

\author{
Ayse Esra Aslan ${ }^{1}$, Faruk Bozda ${ }^{2}$, \& Burcu Aykaç ${ }^{2}$ \\ ${ }^{I}$ Faculty of Education, Istanbul University-Cerrahpasa/Prof. Dr. (Turkey) \\ ${ }^{2}$ Faculty of Education, Istanbul University-Cerrahpasa/Research Assistant (Turkey)
}

\begin{abstract}
Problem: Critical thinking has been the focus of attention for both philosophers and psychology experts since ancient times. Criticism is expressed etymologically in Greek as "critic" or "kritike", and in Latin as "criticus". Ennis, with his essay "Critical Thinking Concept" in Harvard Educational Review (1962), is the pioneer of contemporary critical thinking in the United States. In this article, Ennis tries to clarify the concept of critical thinking and proposes a taxonomy that includes twelve critical thinking structures.

Critical thinking is addressed in the field of education when Dewey started to use the concept of reflective thinking. According to Dewey (1909), reflective thinking is an active, permanent and careful evaluation of any belief or knowledge in the light of the ground that supports it.

According to the Delphi Report prepared by experts in the field of critical thinking (Facione, 1990), critical thinking is the explanation of purposeful, conceptual, methodological, critical or contextual ideas on which the decision is based, self-regulated judgment, resulting in interpretation, analysis, evaluation and inference The main aim of this study is to develop the Turkish version of the critical thinking scale which is an important concept in the evaluation of individual differences.

Method: Psychological test development and adaptation steps will be followed.

Instruments: Watson-Glaser Critical Thinking Appraisal Form S (Short Form) consists of 16 scenarios, 40 items, and 5 sub-tests. The sub-tests are Making Inferences, Recognition of Assumptions, Deduction, Interpretation, Evaluation of Arguments. Parallel forms of the test are available.

Data analysis: In data analysis, factor analysis will be carried out according to the structural equation model after obtaining an available Turkish scale form for linguistic equivalence study.
\end{abstract}

Keywords: Critical thinking, Watson-Glaser critical thinking scale-form S, university students critical thinking ability.

\section{Introduction}

Critical thinking, one of the favorite subjects of education and cognitive psychology, is both a product of intelligence and a thinking skill that develops intelligence. According to the Delphi Report, critical thinking is defined as a purposeful, self - regulatory judgment resulting in interpretation, analysis, assessment and inference, as well as explanation of the evidence, conceptual, methodological, criteriological or contextual considerations on which that judgment is based (Facione, 1990). Socrates developed the method of Socratic Questioning for critical thinking (Schreglmann, 2011), while Dewey (1909, cited in O'Hare, 2004) said that critical thinking under reflective thinking should be considered within the educational objectives. Bloom (Ennis, 1993) includes critical thinking within the group of higher achievements in the taxonomy of educational objectives. Although it is important to develop critical thinking skills within the Turkish National Education objectives, it is observed that this cannot be developed through the implemented curriculum and practice (Ersoy \& Baser, 2011; Bulut, Ertem \& Sevil, 2009). The teacher is evaluated in terms of attitudes and behaviors, teaching methods and creating educational materials in developing critical thinking skill (Alkın-Şahin \& Gözütok, 2013). However, there is a need for a special program and training material prepared by the expert to develop critical thinking (Aybek, 2006; Aybek, 2010; Gürkaynak, Üstel, \& Gülgöz, 2008; Tok \& Sevinç, 2010). The critical intellectual characteristics of the critical thinkers are listed. These are; 1) disciplined features, 2) intellectual integrity, 3) intellectual modesty, 4) intellectual justice, 5) intellectual determination, 6) intellectual objectivity, 7) intellectual confidence in reasoning, 8) intellectual courage, 9) intellectual empathy ( Paul \& Elder, 2013).

${ }^{*}$ This research was carried out with the research scholarship within the scope of project no 36913 in the scientific research projects of Istanbul University. 


\section{Objectives}

The main aim of this study is to develop the Turkish version of the Watson-Glaser Critical Thinking Appraisal Test-Short Form. The long form of the test has been adapted to Turkish previously, however, the validity and the reliability of the test were problematic. In this context, it is aimed to analyze the reliability and the construct validity of the Turkish version of the Watson-Glaser Critical Thinking Appraisal Test- Short Form.

\section{Methods}

In the research, psychometric scale development steps were followed. The sample of the study was selected from the prospective teachers, aged between 18-24, that are enrolled in the education faculty of Istanbul University. Because it is a state university, the students have enrolled in the faculty with a placement test and came from various regions of Turkey. $\mathrm{N}=773$ people from 13 departments within the faculty were reached. Analyzes were performed according to classical test theory and results at least $p<.05$ confidence interval were evaluated.

The linguistic equivalence studies were analyzed with the data collected from a group of $\mathrm{N}=57$ people studying in English language teaching department and have a good mastery of both languages. Firstly, the English form was applied to the study group and after a 15-day interval, the Turkish form was applied. Pearson Product Moment Correlation (r) and related group t-test were used between these two groups of scores.

For reliability applications, Cronbach Alpha analysis was performed. The construct validity was tested within the scope of validity analyzes. Item total, item remainder, and item analysis were performed. For item total and item remainder analysis correlation was used and unrelated group t-test was used for item analysis.

\subsection{Data collection tool}

Watson-Glaser Critical Thinking Appraisal Test-Short Form consists of five subtests and 40 questions. A high level of competency in critical thinking, as measured by the Watson-Glaser, may be operationally defined as the ability to correctly perform the domain of tasks represented by the five tests (Glaser, 2008).

1. Inference. Discriminating among degrees of truth or falsity of inferences drawn from given data.

2. Recognition of Assumptions. Recognizing unstated assumptions or presuppositions in given statements or assertions.

3. Deduction. Determining whether certain conclusions necessarily follow from information in given statements or premises.

4. Interpretation. Weighing the evidence and deciding if generalizations or conclusions based on the given data are warranted.

5. Evaluation of Arguments. Distinguishing between arguments that are strong and relevant and those that are weak or irrelevant to a particular issue.

For each subtest, a reading text and related premises were given. The selected texts are similar to the daily newspaper or journal articles. Test takers are asked to give a judgment/comment to premises depending on the text. For the inference subtest, 5-point Likert scale was used and the other four tests were answered in $1 / 0$ form.

\section{Conclusion and discussion}

The research data were collected from a total number of 219 people $(\mathrm{N}=773$, Nfemale=554, $\mathrm{N}_{\text {male }}=219$ ) from 13 departments of Istanbul University Faculty of Education that educates teacher candidates in various fields. The relationship between the data obtained with English and Turkish test forms that were applied to assess linguistic equivalence was calculated by Pearson Product Moment Correlation Coefficient and statistically significant relationship was determined for all of the subtests as follws; Inference $(\mathrm{r}=.984$, sig. $=.000, \mathrm{t}=-1,694$, sig. $=.000, \mathrm{p}>\mid .05)$, Recognition of Assumptions $(\mathrm{r}=.995$, sig. $=.000$, $\mathrm{t}=1,427$, sig.=.000, $\mathrm{p}>\mid .05)$, Deduction. $(\mathrm{r}=.955$, sig.=.000, $\mathrm{t}=-6,051$, sig.=.000, $\mathrm{p}<.05)$, Interpretation $(\mathrm{r}=.961$, sig.=.000, $\mathrm{t}=-1,000-$, sig.=.322, $\mathrm{p}>\mid .05)$, Evaluation of Arguments $(\mathrm{r}=.981$, sig.=.000, $\mathrm{t}=1,351$, sig. $=.182, \mathrm{p}>\mid .05)$ and for total $(\mathrm{r}=.988$, sig.=.000, $\mathrm{t}=-5,519$, sig.=.000, $\mathrm{p}<.001)$. In addition, meaningless results were obtained except for the deduction subtest in the related group t-test analysis that was performed between the mean values of the two groups. Significant relationships for these analyses are expected to be meaningless t-test. In the reliability analysis, the following Cronbach's Alpha values were obtained for the 
subtests: Inference $(\alpha=.595)$, Recognition of Assumptions $(\alpha=.705)$, Deduction $(\alpha=.705)$, Interpretation $(\alpha=.660)$, Evaluation of Arguments $(\alpha=.695)$. For all subtests, validity analyses were performed because the degree of reliability was considered to be within acceptable limits.

Factor analysis was done for the construct validity of the scale. Factor analysis is a multivariate statistical method that aims to find a less significant number of new variables conceptually by combining a number of interrelated variables (Çokluk, Şekercioğlu \& Büyüköztürk, 2012). For the validity analysis, all sub-tests were accepted as a factor and item total and item remainder analyzes were performed. For these five subtests, a significant result was obtained at $p<.01$ level. This result was interpreted as a pattern between the subtests of the test and the items in terms of measuring critical thinking and the discriminant analysis of the subtests were done. When the same analyses were repeated on the basis of the items covered by the sub-tests, the relationship between the total subtest and the whole test for the validity of the test was accepted, although meaningless results were obtained from the item total and item remainder analysis for some items. Considering the limit values that can be taken into consideration in interpreting the item-total correlation, in general items with a total correlation of 0.30 or higher are known to differentiate the individuals well (Büyüköztürk, 2006, Ennis, 1996).

The use of construct validity of a test provides the internal consistency of the items within the subtests and the subtests within the whole. The correlation coefficient of Person Product Moments is used to determine the correlation. Pearson Product Moment Correlation coefficient is used to find and interpret the relationship between two variables, while regression analysis is used to determine how independent variables explain the changes observed in the dependent variable, whether they predict the dependent variable in a meaningful way and their relative significance on the dependent variable (Büyüköztürk, 2007). In a subsequent study, with confirmatory factor analysis, it can be tested whether subtests predict the five subfactor structures as in the original. Confirmatory factor analysis is a fairly large statistical technique used at a higher level in the testing of related theories and latent variables (Tabachnick and Fidell, 2014). In the confirmatory factor analysis, the researcher specifies in the hypothesis or model that s/he established before the analysis that which variables are related to which dimensions and which dimensions are related to each other (Stevens, 2002). It is possible to see studies, which develop tools to measure the elements that will directly or indirectly affect the critical thinking for different age levels, that apply the structural equation model as another analysis model in the construct validity and factor analysis (Gülveren, 2007; Kayagil \& Erdoğan, 2011; Vural \& Kutlu, 2004). Structural equation model is a statistical technique used for testing models where causal and correlational relationships coexist between observed variables and latent variables. This method is a multivariate method which is formed by combining analysis such as variance, covariance analysis, factor analysis and multiple regression to predict dependency relationships (Tüfekçi \& Tüfekçi, 2006). It is mainly a combination of factor analysis and regression analysis. This analysis tests the compliance of the observed covariance matrix with the covariance matrix according to the theoretical model (Hox \& Bechger, 1995, p. 356). The two basic characteristics of structural equation modeling are as follows (Hair et al., 1998, p. 584); firstly, multiple and interdependent relationships are tested in a single analysis.; secondly, it is assumed that the indicator variables cannot be measured perfectly and error variances of the indicators are included in the calculations.

\section{References}

Alkın-Şahin, S. \& Gözütok, F. D. (2013). Eleştirel düşünmeyi destekleyen öğretmen davranışları envanteri (EDDÖDE): Geliştirilmesi ve uygulanması [Critical thinking supportive teacher behaviors inventory (CTSTBI): Its development and application]. Eğitim Bilimleri Araştırmaları Dergisi - Journal of Educational Sciences Research, 3(2), 223-254. http://ebad-jesr.com/

Aybek, B. (2006). Konu ve beceri temelli eleştirel düşünme öğretiminin öğretmen adaylarının eleştirel düşünme eğilimi ve düzeyine etkisi [The effect of subject-based and skill-based critical thinking teaching on the critical thinking disposition and level of teacher candidates.]. (Unpublished doctoral dissertation). Çukurova University Institute of Social Sciences Department of Educational Sciences.

Aybek, B. (2010). Örneklerle düşünme ve eleştirel düşünme [Thinking and critical thinking with examples]. Ankara: Nobel Publishing.

Bulut, S., Ertem, G. \& Sevil, Ü. (2009). Hemşirelik öğrencilerinin eleştirel düşünme düzeylerinin incelenmesi [Examining the critical thinking levels of nursing students]. Dokuz Eylül Üniversitesi Hemşirelik Yüksekokulu Elektronik Dergisi- Dokuz Eylül University Electronic Journal of School of Nursing, 2(2), 27-38.

Büyüköztürk, Ş. (2007). Veri analizi el kitabı [Handbook of data analysis]. Ankara: PegemA Publishing.

Çokluk, Ö., Şekercioğlu, G., \& Büyüköztürk, Ş. (2012). Sosyal bilimler için çok değişkenli istatistik spss ve lisrel uygulamalarl [Multivariate statistics spss and lisrel applications for social sciences]. Ankara: PegemA Publishing. 
Doğan, N. (2013). Eleştirel düşünmenin ölçülmesi [Measurement of critical thinking]. Cito Eğitim: Kuram ve Uygulama- Cito Education: Theory and Practice, 22, 29-42.

Dutoğlu, G. \& Tuncel, M. (2008). Aday öğretmenlerin eleştirel düşünme eğilimleri ile duygusal zeka düzeyleri arasındaki ilişki [The relationship between the teacher candidates' critical thinking dispositions and the levels of emotional intelligence]. Abant İzzet Baysal Üniversitesi Ĕgitim Fakültesi Dergisi- Abant Izzet Baysal university journal of Education Faculty, 8(1);11-32.

Ennis, R. H. (1993). Critical thinking assessment. Theory into practice, 32 (3), 179-186.

Ersoy, E. \& Başer, N. (2011). İlköğretim ikinci kademede eleştirel düşünmenin yeri [The place of critical thinking in the secondary stage of primary education]. Adnan Menderes Üniversitesi Ĕgitim Fakültesi Eğitim Bilimleri Dergisi- Adnan Menderes University Journal of Educational Sciences, 2(1), 1-10. http://dergi.adu.edu.tr/egitimbilimleri/

Facione, P. (1990). Critical thinking: A statement of expert consensus for purposes of educational assessment and instruction (The Delphi Report).

Gülveren, H. (2007). Ë̆itim fakültesi öğrencilerinin eleştirel düşünme becerileri ve bu becerileri etkileyen eleştirel düşünme faktörleri [Critical thinking skills of the faculty of education and critical thinking factors affecting these skills]. (Unpublished doctoral dissertation). Dokuz Eylül University Graduate School of Educational Sciences, İzmir.

Gürkaynak, İ, Üstel, F., \& Gülgöz, S. (2008). Eleştirel Düşünme, [Critical thinking]. $3^{\text {rd }}$ Edition. Education Reform Initiative (ERI) reports.

Hair, J.F., R.E. Anderson, R.L. Tahtam \& W. C. Black (1998). Multivariate data analysis. Prentice Hall International Inc., New Jersey.

Hox, J.J. ve T.M. Bechger (1995). An introduction to structural equation modeling. Family Science Review, $11,354-373$.

Kartal, T. (2012). İlköğretim fen Bilgisi öğretmen adaylarının eleştirel düşünme eğilimlerinin incelenmesi [An investigation of the critical thinking disposition of elementary science teacher candidates]. Ahi Evran Üniversitesi Kırşehir Eğitim Fakültesi Dergisi- Ahi Evran University Kırşehir Educational Faculty Magazine (KEFAD), 13(2); 279-297.

Kayagül, S. \& Erdoğan, A. (2011). Bazı değişkenlerin ilköğretim yedinci sınıf öğrencilerinin eleştirel düşünme becerilerini yordama gücü [The prediction level of some variables in elementary school seventh grade students' critical thinking skills]. Selçuk Üniversitesi Ahmet Keleşoğlu Ĕgitim Fakültesi Dergisi- Selçuk University Ahmet Keleşoğlu Journal of Education Faculty, 31, 21-334.

O'Hare, L. C. (2005). Measuring critical thinking skills and dispositions in undergraduate students. (Unpublished doctoral dissertation). Queen's University Belfast Faculty of Science and Agriculture, Northern Ireland.

Paul, R. \& Elder, L. (2013). Kritik düşünce: Yaşamınızın ve öğrenmenizin sorumluluğunu üstlenmek için araçlar [Critical thinking: Tools for taking charge of your learning and your life]. $3^{\text {rd }}$ Edition. İstanbul: Nobel Akademi.

Schreglmann, S. (2011). Konu temelli eleştirel düşünme ögretiminin öğretmen adaylarının akademik başarl, eleştirel düşünme eğilimine ve düzeyine olan etkisi [The effect of subject-based critical thinking teaching on the academic achievement, critical thinking disposition level of teacher candidates]. (Unpublished Master Thesis). Çukurova University Institute of Social Sciences, Adana.

Stevens, J. P. (2002). Applied multivariate statistics for the social sciences. New Jersey: Lawrance Erlbaum Association, Inc

Tabachnick, B. G. \& Fidel, L. S. (2014). Using multivariate statistics. USA: Pearson Education Limited.

Tok, E. \& Sevinç, M. (2010). Düşünme Becerileri Eğitiminin Eleştirel Düşünme ve Problem Çözme Becerilerine Etkisi [Effects of Thinking Skills Training on Critical Thinking and Problem Solving Skills]. Pamukkale Üniversitesi Eğitim Fakültesi Dergisi- Pamukkale University Faculty of Education Journal, 27, 67-82.

Tüfekçi, N. \& Tüfekçi, Ö. K. (2006). Bankacıllk sektöründe farklı olma üstünlügünün ve müşteri sadakatinin yarattığı değer: Isparta ilinde bir uygulama [The advantage of being different in the banking sector and customer loyalty: An application in the province of Isparta]. Süleyman Demirel Üniversitesi Sosyal Bilimler Enstitüsü Dergisi- Journal of Süleyman Demirel University Institute of Social Sciences, 2(4), 170-183.

Vural, R. A. \& Kutlu O. (2004). Eleştirel düşünme: Ölçme araçlarının incelenmesi ve bir güvenirlik çalışması [Critical thinking: Examination of measurement tools and a reliability study]. Sosyal Bilimler Enstitüsü Dergisi- Journal of Social Sciences Institute, 13(2), 189-200.

Watson, G., \& Glaser, E. M. (2008), Watson-Glaser Critical Thinking Appraisal Short Form, USA: Pearson Education, Inc.

Yıldırım, H. İ. \& Şensoy, Ö. (2011). İlköğretim 7. Sınıf öğrencilerinin eleştirel düşünme eğilimi üzerine eleştirel düşünme becerilerini temel alan fen öğretiminin etkisi [The effect of science teaching based on critical thinking skills on 7th grade students' critical thinking disposition]. Kastamonu Eğitim Dergisi- Kastamonu Education Journal, 19(2); 523-540. 